\title{
Stemming the Global Trade in Falsified and Substandard Medicines
}

Lawrence O. Gostin

Georgetown University Law Center, gostin@law.georgetown.edu

Gillian J. Buckley

Institute of Medicine

Patrick W. Kelley

Institute of Medicine

Georgetown Public Law and Legal Theory Research Paper No. 13-033

This paper can be downloaded free of charge from:

https://scholarship.law.georgetown.edu/facpub/1209

http://ssrn.com/abstract=2259119

309 JAMA 1693-1694 (2013)

This open-access article is brought to you by the Georgetown Law Library. Posted with permission of the author. Follow this and additional works at: https://scholarship.law.georgetown.edu/facpub

Part of the Food and Drug Law Commons, Health Law and Policy Commons, Pharmaceutics and Drug Design Commons, and the Pharmacy Administration, Policy and Regulation Commons 


\section{Stemming the Global Trade in Falsified and Substandard Medicines}

Lawrence O. Gostin, JD

Gillian J. Buckley, MPH, PhD

Patrick W. Kelley, MD, DrPH

W

Hen Hippocrates ADVISED PHYSICIANS TO

never give a deadly drug, he assumed they would know for sure that the medicines they prescribed were safe. Today, criminals and unscrupulous manufacturers have permeated the global pharmaceutical market, calling into question this basic assumption of clinical practice. Between November 2012 and March 2013, an injectable drug compounded under unhygienic conditions at the New England Compounding Pharmacy was linked to more than 700 illnesses and 50 deaths. ${ }^{1}$ In poor countries, where drug regulatory oversight is weaker, the problem is worse, but blends with the background noise of high mortality and strained health systems. Only in rare cases, as when 120 Pakistanis died after taking a carelessly made batch of isosorbide mononitrate, do people in low- and middle-income countries learn of their vulnerability. ${ }^{2}$

The pharmaceutical trade is transnational, lucrative, and extensive; the United Nations Office on Drugs and Crime estimates the value of the illegal antimalarial drug market in west Africa alone exceeds $\$ 400$ million. ${ }^{3}$ These products pose immense dangers. Falsified and substandard drugs may contain no active pharmaceutical ingredient or contain the active ingredient at subtherapeutic doses. Poor-quality antimicrobial drugs are a major problem in Southeast Asia and sub-Saharan Africa, ${ }^{4,5}$ where they contribute to drug resistance, reducing a drug's effectiveness. Society must bear the cost of developing alternate therapies. Poor-quality products increase health care costs, while causing patients to lose confidence in the health system.

In a report released recently, an Institute of Medicine expert committee examined the causes of, and solutions to, the problem of falsified and substandard drugs in the United States and globally. ${ }^{6}$

\section{A Common Language}

At the heart of the problem is a lack of a common language. Some emerging manufacturing nations and civil society groups object to using the broad descriptor counterfeit for all poor-quality drugs. In a narrow sense, counterfeit products are only those that infringe on a registered trademark. Stakeholders concerned with access to generic medicines fear that action against counterfeit drugs would mean stricter enforcement of intellectual property rights, thereby reducing the availability of inexpensive generics.

To avoid confusion, the term counterfeit should be used only to describe a trademark infringement. Medicines posing a public health concern include 2 overlapping categories. A falsified drug misrepresents the product's identity, source, or both. A substandard drug fails to meet national specifications in accepted pharmacopoeia or the manufacturer's dossier. This language frames falsified and substandard medicines exclusively as a public health problem. Consistent use of these terms would facilitate clear communication among regulators, police, and industry. A common language would allow for more accurate measurement of the scope and trends at the national and global levels.

\section{Pharmacovigilance}

There are no reliable estimates of the global burden of falsified and substandard medicines. The World Health Organization has a promising pilot approach to train regulators for drug quality surveillance in 10 developing countries, using rapid alert forms to identify dangerous products and link incidents across different countries. Governments should establish or strengthen systems to detect and monitor substandard and falsified medicines, integrating pharmacovigilance into routine national surveillance. Quality surveillance would improve understanding of the types of products compromised and the extent of the trade.

\section{Track and Trace}

A porous global supply chain allows good medicines to be diverted to the illicit market and poor-quality medicines to enter the legal one. Securing the medicines' chain of custody would protect the drug supply. Track and trace systems empower stakeholders to know a drug's location and authenticity throughout the distribution chain. A federal track and trace system would enable companies to follow a uniform standard without state variations. Therefore, Congress should authorize and fund the Food and Drug Administration (FDA)

Author Affiliations: Georgetown University Law Center (Mr Gostin) and the Board on Global Health, Institute of Medicine (Drs Buckley and Kelley), Washington, DC. Corresponding Author: Lawrence O. Gostin, JD, Georgetown University Law Center, 600 New Jersey Ave NW, Washington, DC 20001 (gostin@law.georgetown.edu).

JAMA, April 24, 2013-Vol 309, No. $16 \mathbf{1 6 9 3}$ 
to establish a mandatory track and trace system. In the interim, the FDA should convene stakeholders to promote voluntary track and trace for all supply chain actors. FDA action would protect the US consumer, while building momentum for tighter medicine controls internationally.

\section{Wholesale Licensing}

Secondary wholesalers and state standards vary widely. States license wholesalers, with standards varying widely. Unscrupulous firms seek out states with weak oversight. Because the wholesale market is national, weaknesses in one state's system threaten the others. To rectify this problem, states should grant licenses only to wholesalers meeting the National Association of Boards of Pharmacy accreditation standards. The FDA could promote openness in the licensing process by creating a public database to share information on suspended and revoked wholesale licenses. Tight accreditation and transparent information sharing would help thwart irresponsible wholesalers.

\section{Quality Manufacturing}

Drug production depends on good manufacturing practices and quality control. Small- and medium-sized drug companies in developing countries lack the infrastructure, equipment, and staff necessary to meet international standards. These firms do not operate on a scale that allows them to recover the costs of running a modern factory, and they have few avenues to raise capital from national banks. The World Bank's International Finance Group and the US government's Overseas Private Investment Corporation should invest in pharmaceutical manufacturing in developing countries. Companies that avail themselves of loans can raise their standards, thus providing inexpensive, quality medicines in a market starved for them.

\section{Drug Retail}

The private sector also has a role in improving drug retail in developing countries, where the poor often have no choice but to purchase drugs from unlicensed shops or open-air markets. These markets violate many basic principles of responsible pharmacy practice: tablets are sold loose, blister packs cut apart, and secure storage is rare. Shopkeepers have no training in the proper handling or buying of medicines. Inasmuch as development finance organizations can help good-faith manufacturers, governments can use training, franchising, and accreditation schemes to create better drug retail. National pharmacy councils can improve workforce efficiency by assigning some pharmacy tasks to technicians, a process known as task shifting. Vocational training in dispensing medicines, combined with incentives to re- tain trained staff in rural areas and slums, would improve medicines' retail in the poorest countries.

\section{International Code of Practice}

National regulatory authorities have the final responsibility for a country's drug supply: preventing falsified and substandard drugs from entering the market, detecting them when they do, and punishing unscrupulous actors. However, no country acting alone can protect its inhabitants from falsified and substandard medicines.

The World Health Organization has the constitutional authority to promulgate an international code of practice, a type of voluntary soft law, pertaining to falsified and substandard medicines. This code would catalyze stakeholder action and coordinate regulatory, customs, and law enforcement agencies. The World Health Assembly, in partnership with United Nations Office on Drugs and Crime and the World Customs Organization, should develop the code using an open and inclusive process. The code would offer guidance on standard terminology, surveillance, regulation, and law enforcement. It would set clear targets, monitor results, and mobilize resources and technical assistance for low- and middle-income countries. Most importantly, the code would promote international cooperation and multisector action against the criminal syndicates that poison the world's medicine supply.

Published Online: April 11, 2013. doi:10.1001/jama.2013.3048 Conflict of Interest Disclosures: All authors have completed and submitted the ICMJE Form for Disclosure of Potential Conflicts of Interest. Dr Gostin reported serving as the chair of the Institute of Medicine's Committee on Countering the Problem of Falsified and Substandard Drugs, a consensus study contracted by the US Food and Drug Administration. Dr Buckley reported serving as study director of the Institute of Medicine's Committee on Countering the Problem of Falsified and Substandard Drugs. Dr Kelley reported serving as director of the Institute of Medicine's Board on Global Health. He oversaw the project.

1. Centers for Disease Control and Prevention. Multistate Fungal Meningitis Outbreak Investigation-Current Case Count. http://www.cdc.gov/hai/outbreaks /meningitis-map-large.html. Updated March 11, 2013. Accessed March 21, 2013. 2. Arie $\mathrm{S}$. Contaminated drugs are held responsible for 120 deaths in Pakistan. BMJ. 2012;344:e951.

3. United Nations Office on Drugs and Crime. Transnational Trafficking and the Rule of Law in West Africa: A Threat Assessment, July 2009. Vienna, Austria: United Nations Office on Drugs and Crime; 2009.

4. Nayyar GML, Breman JG, Newton PN, Herrington J. Poor-quality antimalarial drugs in southeast Asia and sub-Saharan Africa. Lancet Infect Dis. 2012;12 (6): $488-496$

5. Bate R, Jensen P, Hess K, Mooney L, Milligan J. Substandard and falsified antituberculosis drugs: a preliminary field analysis. Int J Tuberc Lung Dis. 2013; 17(3):308-311

6. Institute of Medicine of the National Academies. Countering the Problem of Falsified and Substandard Drugs. Washington, DC: National Academies Press; 2013.

7. World Health Organization. Building Global Capacity for Surveillance and Monitoring of "Substandard/Spurious/Falsely-labelled/Falsified/Counterfeit" Medicines [information leaflet for National Medicines Regulatory Authorities]. 2012. 